\title{
Making Rules for Governing Global Commons
}

\author{
THE CASE OF DEEP-SEA MINING
}

\author{
THOMAS BRÄUNINGER \\ THOMAS KÖNIG \\ University of Konstanz
}

\begin{abstract}
Acentral goal of the Third United Nations Conference on the Law of the Sea 1973-1982 was to establish an international order for the use of the deep seabed beyond national jurisdiction. An overwhelming majority of countries signed the comprehensive convention, but several countries-including the industrialized G7 members Italy, the United Kingdom, the United States, and the former West Germany - rejected the new ocean regime in 1982. This article addresses the question of why some states opposed the 1982 convention by examining their preferences for alternative decision-making rules. A policy-seeking approach is used by deriving the preferences of 149 states for different decision-making rules from three components: states' preferences for policies, the working properties of different decision-making rules, and the location of the status quo. Findings show why the 1982 proposal failed to be supported by the main industrialized countries. Some evidence exists for the successful foundation of a multicameral rule in 1994.
\end{abstract}

\section{HOW TO GOVERN THE USE OF DEEP-SEA RESOURCES}

In 1982, after an 8-year marathon of negotiations, the Third United Nations Conference on the Law of the Sea (UNCLOS III) announced the adoption of a convention for governing the world's oceans. An overwhelming majority of the 149 countries signed the comprehensive convention of 320 articles and 9 annexes. They agreed on the regulation of nearly every major issue of ocean use, including transport, transit and overflight, fisheries, oil and mineral resource exploitation, use and environmental protection of the deep seabed, and the high and territorial seas. ${ }^{1}$ Several countries, however, rejected the new ocean regime in 1982-among these were the industrialized G7 members Italy, the United Kingdom, the United States, and the former West Germany. A large part of the international community was in favor of the new regime, but the

1. United Nations Convention on the Law of the Sea, U.N.Doc. A/CONF.62/122, 10December 1982.

AUTHORS' NOTE: We are grateful to Robert L. Friedheim, University of Southern California, Los Angeles, for providing the data. 
industrialized states were in opposition to the convention's Part XI establishing the International Seabed Authority (ISA) (Friedheim 1993, 27-40). The ISA was vested with power to administer and govern the use of the seabed's manganese nodule resources that were regarded as highly important for national economies in the future.

Because the seabed is beyond national jurisdiction, existing international law had previously granted all states free access to the global commons of the deep seabed. However, the common view was that uncontrolled use of the deep seabed would end up in a rapid and one-sided exploitation of the resources. It would be unfair from the global commons standpoint and have adverse economic effects on the long-term performance of the world metal markets. Rejection by the economically and politically important countries - producing more than $60 \%$ of the world's gross national productsubstantially endangered the new regime in two ways. There was no restriction on the free use of manganese nodules by the few opposing countries having the capacity to exploit seabed resources. As a result, the regime and the universality of the convention were endangered. Under these circumstances, the Group of 77 , as the largest coalition of developing countries in the United Nations articulating and promoting collective economic interests, signaled its willingness to renegotiate ISA issues in 1989. Five years later in July 1994, just before the convention came into force, the United Nations General Assembly set up an implementation agreement to ensure the universality of the convention, making major concessions to the disgruntled highly industrialized countries. ${ }^{2}$ The latter finally won reduced production limitations and more weight in the ISA decision-making procedures (Anderson 1995; Hayashi 1996).

The history of UNCLOS III has attracted considerable attention in the international relations literature, especially the ISA framework on the governance of the deep seabed (Hollick 1981; Sebenius 1984; Schmidt 1989; Young 1989). Most studies focus on questions of how to deal with the use of the global commons: how to allocate user rights, levy fees, and guarantee the compliance of the resource management. Despite numerous provisions on these matters, the convention serves as a guideline defining the general principles for the future governance of the use of deep seabed resources. Almost all substantial policies, however, will be decided by member states within the ISA. Hereby, the renegotiated ISA provisions established a rather unique multicameral system that grants collective veto rights to specific interest groupsnamely, investors in deep-sea mining, major consumer states, and producers of the minerals in question. According to Figure 1, states belonging to the specific groups are more likely to occupy a seat in one of the four council chambers and attain a veto on majority decisions, whereas most developing countries and nonspecific states have lower chances to be elected in the council. ${ }^{3}$ Under these multicameral provisions, both the large part of the international community and the highly industrialized countries

2. Agreement relating to the implementation of Part XI of the United Nations Convention on the Law of the Sea of 10 December 1982, U.N. Doc. A/RES/48/263, 28 July 1994.

3. Law of the Sea Convention, Article 161 (1). The third group comprises states that are major exporters of the minerals in question. Because the land-based production will exceed the seabed production in the near future, we only consider states that are land-based producers. 


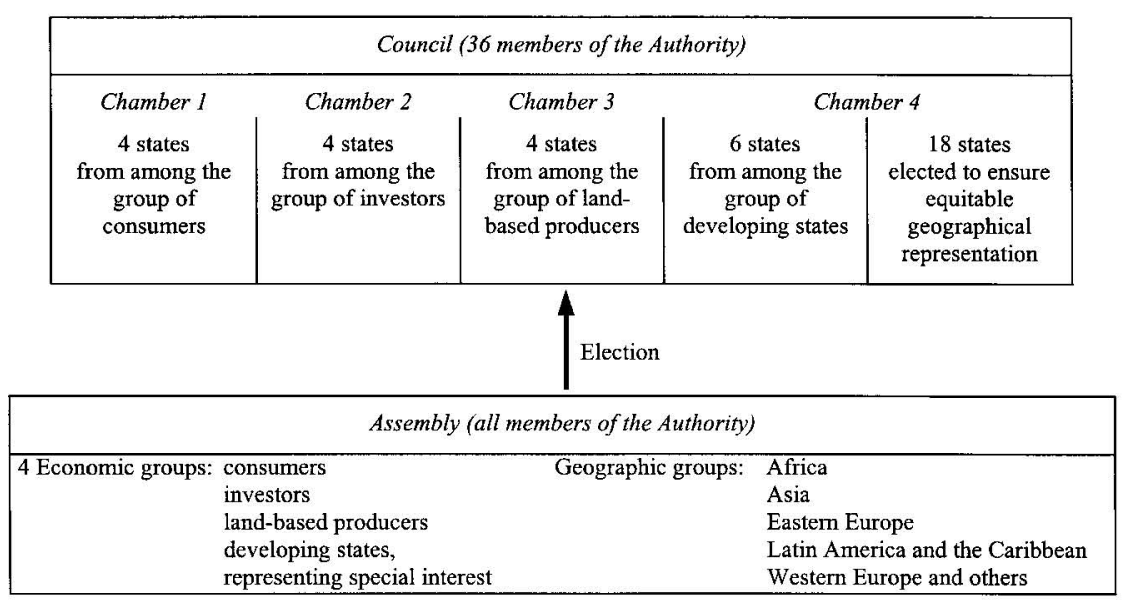

Figure 1: Group Representation in the Council

were willing to collaborate in protecting and using the global commons of the deep seabed.

Nevertheless, the question of how to explain the choice of ISA rules and multicameral procedures for ISA decision making has received little attention. In his study on the convention's basic financial arrangements, Sebenius (1984) stresses the longterm horizon of the deep-sea mining regime. He considers differences in probability assessment, risk aversion, and time preferences of the states, but he does not take into consideration the problem of rule making. Friedheim $(1993,256)$ puts emphasis on the distinct and central issue of how to design rules for future decision making within the ISA when noting, "Whoever controlled its [ISA] decisions essentially controlled the effort to mine the deep seabed. This was clearly understood by the politically experienced delegations." Even though Friedheim regards the constitutional issue of rule making as of utmost importance, he does not take the long-term working properties of rules into account when considering rule making as another substantial policy issue to be solved by the delegates. Moreover, there is no evidence explaining why the 149 countries could not agree on multicameral rules establishing collective veto rights for consumers, producers, investors, and developing countries in 1982.

In this article, we look conceptually and empirically at the question of how states designed the multicameral rules for ISA decision making. We start from the assumption that rules are not valued on their own merits, but states favor rules that are likely to provide the policies they prefer (Mueller 1996, 62). To consider both the durability and complexity of rule making, we conceptually distinguish between an interest component and a theory component of rule making. Although the former concerns the subjec- 
tive evaluation of expected policy outcomes, the theories are the predictions (assumptions, beliefs) of what the factual outcomes of alternative rules will be (Vanberg and Buchanan 1989,52). We consequently use expected utility theory to transform preferences over policies to preferences over complex rules. Our findings show that we can explain the configuration in 1982 in terms of not only the supporters but also the opponents of the originally proposed ISA rules. Moreover, we find reasons for multicameral group representation and collective veto rights in the similarity of certain states' policy positions, both guaranteeing the success of the 1994 proposal.

In the remainder of this article, we first present our approach to actors' transition from policy positions into rule preferences. Second, we introduce the six seabed mining policies that were directly connected to ISA decision-making rules. Finally, we apply our approach to the prediction of states' preferences for the delegation of ISA decision-making rules. Using data from 149 states participating in UNCLOS III, we test our results by comparing predicted preferences and states' (dis)agreement on the rules of the ISA's key decision-making organ, the 36-member council.

\section{THE THEORY AND INTEREST COMPONENTS OF CONSTITUTIONAL CHOICE}

When addressing questions about international institution building, it is useful to start with the distinction between evolutionary concepts of spontaneous order and social selection at the system level and concepts of intentional design of purposive acting entities (Knight and Sened 1995, 3). Although evolutionary accounts have mostly been evoked to explain the emergence of informal institutions such as social conventions or norms (e.g., Axelrod 1984), the design of formal political institutions has primarily been considered as a result of the purposive choice of constitutional actors (e.g., Tsebelis 1990). To explain the choice of the ISA decision-making rules or, more generally, decision-making rules in international regimes or organizations, we apply the actor-oriented idea of rule making by intentional design. As states seek to coordinate their behavior in international politics to avoid suboptimal outcomes, their interests in the policy outcomes that institutions are expected to produce should provide insight into the process of institution building by international negotiations. Of course, states may prefer rules for reasons other than policy interests (e.g., when considering consistency with their own ideas of equity, fairness, or democratic government). The more fundamental assumption, however, is that rules are not valued on their own merits but rather on their likely effects on policy outcomes.

In conducting an empirical analysis of the constitutional choice of decision-making rules, we are faced with the problem of how to measure actors' predictions about what the factual outcomes of alternative rules will be. Negotiations may increase actors' information about their present policy positions and those of other actors, but their knowledge of future outcomes is often imperfect or may even be lacking. And rules may differ with regard to at least the voting quota to individual voting rights like agenda setting, amending, and vetoing, the latter establishing formal prerogatives for some actors. In this regard, not just actors' future goals but also their theories about the work- 
ing properties of alternative rules and rule systems are crucial to their choice behavior at the constitutional level (Ostrom 1990, 192-95). To capture the difference between the choice of policies and rules, we propose to distinguish between three components.

Interest component. The first key variable that we consider to determine actors' preferences regarding different rules are their policy positions or interests in policies. Interests refer to the subjective evaluation of expected outcomes, an evaluation that cannot be true or false, correct or incorrect (Vanberg and Buchanan 1989, 52). For the purpose of analysis, we assume that constitutional actors know their own and other actors' current positions on the policies in question, which serve them as "best estimates" for their future policy positions.

Theory component. A second key element is the impact of rules on outcomes. Constitutional actors cannot possibly know the exact effects of different rule systems, but they certainly have expectations about the working properties of different rules. We measure these expectations using two working properties, inclusiveness and decisiveness. The former refers to an actor's probability of being included in future winning coalitions, the latter to his or her probability of deciding the outcome.

Status quo component. The third element is the status quo, which comprises all relevant marginal conditions of the decision-making situation. The location of the status quo defines both the incentives and constraints for decision making. In the following, we assume all actors know the current location of the status quo that serves as the best estimate for the future one.

Linking the three key elements of the interest, theory, and status quo component, we model the transition from actors' policy positions to rule preferences. For this purpose, we use a cooperative game-theoretical approach that is based on two assumptions.

First, there are external or internal mechanisms that make outcomes binding and enforceable. We think this assumption is not too unrealistic for our analysis for two reasons: ISA decisions have legislative character, meaning that they bind all states even by majority vote without requiring further ratification or providing for opting-out procedures (Sommer 1996, 653). As an exception to existing international law, the ISA disputes settlement procedure is also of binding nature. According to the convention's Article 39 of Annex VI, "the decisions of the Seabed Disputes Chamber shall be enforceable in the territories of the State Parties in the same manner as judgments or orders of the highest court of the State Party in whose territory the enforcement is sought" (El-Baghdadi 1990-1991, 180-81).

Second, in accordance with constitutional analysis, we suppose that constitutional actors lack knowledge about which coalition will finally be formed in the future (Buchanan and Tullock 1962,78). They consider all feasible coalitions but, in contrast to standard assumptions of constitutional analysis, take their existing different interests into account. They thus acknowledge that actors with similar policy positions are more likely to collaborate with them than actors with dissimilar policy positions. Hence, when deriving their expected utilities from future decision making, they con- 
sider homogeneous coalitions (with actors having similar policy positions) more likely to form than heterogeneous coalitions (with actors having dissimilar policy positions) (see appendix, equations A1-A3).

Under these assumptions, we use the two concepts of inclusiveness and decisiveness to study the impact of voting quota and voting weights: single or collective veto rights characterizing the working properties of multicameral systems (see appendix, equations A4-A7). The formation of rule preferences can then be explained by expected benefits from future policy outcomes regulated by specific voting rules. Assuming that any member $i$ of the actor set $N$ assesses outcomes to utility functions $U^{i}=U^{i}(x)$, the expected utility $E U_{j, t}^{i}$ of each actor $i$ for any rule $j$ regarding issue $t$ can formally be derived from a risky lottery of coalition building (see appendix, equations A8-A9):

$$
E U_{j, t}^{i}=\sum_{S \subseteq N} \pi_{t}(S) U^{i}\left(x_{j, t}(S)\right),
$$

where $\pi_{t}(S)$ is the probability of coalition $S$, and $x_{j, t}(S)$ is its expected policy outcome depending on rule $j$.

Finally, we suppose that actors derive their rule preferences when maximizing their expected utility functions: for any issue $t$, actor $i$ will prefer rule $j$ to rule $k$ if and only if $E U_{j, t}^{i}$ is greater than $E U_{k, t}^{i}$. This serves us as the starting point of an actor-oriented constitutional choice analysis studying the problem of how to select a single rule. We approach this question by considering all actors' expected utilities from changing the current rule. Arranging their expected utilities from a change of the current setting yields

$$
\Delta E U_{t}=\left(\begin{array}{ccc}
E U_{1, t}^{1}-E U_{r e f, t}^{1} & \cdots & E U_{m, t}^{1}-E U_{r e f, t}^{1} \\
\vdots & \ddots & \vdots \\
E U_{1, t}^{n}-E U_{r e f, t}^{n} & \cdots & E U_{m, t}^{n}-E U_{r e f, t}^{n}
\end{array}\right)
$$

In this "constitutional matrix" $\Delta E U_{t}$, the $i$ th row depicts the expected surplus of actor $i$ under the change from the current setting ref to different rules in question; the $j$ th column of $\Delta E U_{t}$ denotes the expected surplus for actors when the current setting is changed to rule $j$ (i.e., whether a voting rule satisfies the criterion of Pareto superiority with respect to issue $t$ ).

Before applying our approach to the study of deep-sea mining delegates' preferences, we present our data on the policy space of the 149 states that participated in the UNCLOS III negotiations. For our empirical purpose, a major task is to identify states' policy positions and the legal status quo on major deep-sea mining issues as well as the set of feasible rules.

\section{DATA: THE CASE OF DEEP-SEA MINING}

There has been a "regime of the ocean for millennia" (Friedheim 1993, 11) namely, the ancient regime described and codified by the Dutch legal scholar Hugo 
Grotius in the early 17 th century. Accordingly, rights and obligations of ocean users traditionally have been delineated from the principle of freedom of the seas. Statesalso on behalf of their subjects - could exploit the ocean resources, provided that their usage did not interfere with others' rights of open access. This Grotian ocean regime was first put into question in the middle of the 20th century when President Truman claimed for the United States the right to control fishing and exploit the mineral resources of the continental shelf. In the 1950s, the newly independent states of the developing world also demanded that the Grotian principle had to be abolished. In their view, the freedom of the seas resulted in an asymmetric exploitation of the ocean resources by those states with the necessary technology, finance, and maritime power.

Due to this asymmetry in global resource distribution, developing countries fundamentally challenged the principle of the freedom of the high seas, and the $1970 \mathrm{~s}$ debates about the new international economic order added an ideological dimension to the ocean question (Joyner and Martell 1996, 76). Before, scientific reports on deep-sea resources had stressed both the technological feasibility of deep-sea mining and its growing importance for the future world supply of some key noniron metallic raw materials, including cobalt, copper, and nickel (Mero 1965; Nyhart 1978). The fact that the mineral resources of the deep seabed were not used at the time of UNCLOS III offered a large bargaining space of distributive politics in which states were able to maneuver. To identify the conditions for ISA creation, we next take a closer look at the legal status quo of deep-sea mining and identify states' preferred policies regarding deep-sea mining.

\section{THE LEGAL STATUS QUO OF DEEP-SEA MINING AND INCENTIVES FOR CHANGE}

Existing international law allowed for neither national nor private claims of deepsea property rights, which posed severe problems for an arrangement on the seabed resource system. Like outer space or Antarctica, the area has been treated as res communis or res nullis with quite different meanings (Brown 1983, 525; Beyerlin 1996, 609). According to the res nullis perspective, the seabed belongs to no one. As a result, the seabed's resources are available to anyone capable of recovering them. The res communis viewpoint rather implies that the seabed is owned by all states or peoples (Joyner and Martell 1996, 75). Although most industrialized maritime states favored the res nullis conception, small and developing countries based their claim on the res communis perspective. The seabed should be considered as a "common heritage of mankind," implying that its resources are to be shared by all nations irrespective of their technological capabilities. When the negotiations on deep-sea mining started, international law provided no binding obligation that would have hindered states from exploiting the deep seabed on their own. The property rights for the area were thus characterized by "open access," where no user rights have been attached to specific groups, resulting in a general free-for-all (Edwards and Steins 1998, 348).

The motivation for the start of negotiations was the common view that open access does not provide adequate incentives to use the mineral resources in a responsible way: investors were interested in legally secure rights, consumers in stable metal markets, and developing countries in restricting an intense and asymmetric exploitation of the 
ocean resources by those industrialized states with the necessary technology. The attempt to find ways to transform an open access into a public property resource system gave the negotiations on the deep-sea regime a general importance for future international cooperation. Delegates tried to solve problems of controlling and administering global commons such as air and water. However, when negotiating the deep-sea property rights regime, increasing economic expectations and legal ambiguity caused intense controversies. Because deep-sea mining was considered to have a direct impact on national economies due to their economic, technical, and geographic preconditions, the negotiations about the regime became a touchstone for the questions about the conditions under which industrialized and developing countries would be willing to protect and use the global commons. The crucial question was whether the delegations could find decision-making rules that were preferable to the status quo for all state parties.

\section{ACTORS' POSITIONS ON SIX DEEP-SEA MINING POLICIES}

Applying the principle of state sovereignty, it is a common view that the foundation of an international regime needs the consent of all state parties to improve the status quo. To assess states' incentives to change the status quo, we elaborate the structure of states' positions on ISA policies. This requires an empirical delineation of the bargaining space that we reduce to those ISA policies endowed with rules for future decision making. Even though ISA policies were part of the broader UNCLOS III negotiations, we concentrate on ISA decision-making rules to check whether they provide sufficient insight on the failure of the 1982 negotiations. Of course, linkage with other UNCLOS III topics such as navigational rights has allowed for package deals offering side payments to compensate expected losses from establishing ISA decision-making rules (Sebenius 1984, 80). In this respect, the convention's provisions for convening a review conference and, even more important, the provisions mandating the sale of technology to developing countries later became major topics of contention. But because industrialized countries preferred to keep the status quo of no transfer adding the technology transfer issue to the bargaining space would not give us additional insight into the reasons for the failure of the 1982 convention.

The 149 states' divergent interests in the deep-seabed policies provided with rules for decision making can be illustrated by actors' (dis)similarity of policy positions. To identify policy positions and corresponding status quo locations, we use data from thematic content analysis of official conference records. ${ }^{4}$ Because our primary concern is the choice of rules, we ignore both the two-level logic of international cooperation and the principle-agent problem between national governments and their delegates and between national electorates/interest groups and governments (Putnam 1988; Evans, Jacobson, and Putnam 1993; Pahre and Papayoanou 1997). We use a system-centered approach of international cooperation and conceive states as unitary actors with dele-

4. Data were collected and coded by the United Nations Law of the Sea project directed by Professor Robert L. Friedheim. The project was to provide analytical and forecasting capabilities for the U.S. delegation at UNCLOS III and lasted from 1969 to 1975 (Friedheim 1993). 
TABLE 1

States' Preferences on Seabed Mining Policies

\begin{tabular}{|c|c|c|c|c|c|c|c|c|c|c|c|c|}
\hline \multirow[b]{4}{*}{ Policy/Range } & \multirow[b]{4}{*}{ Topic } & \multicolumn{10}{|c|}{ Number of States/Status Quo } & Salience \\
\hline & & \multicolumn{10}{|c|}{ Ideal positions } & \multirow[b]{3}{*}{ Mean } \\
\hline & & \multicolumn{4}{|c|}{ Not Regulated } & \multicolumn{6}{|c|}{ Highly Regulated } & \\
\hline & & 1 & 2 & 3 & 4 & 5 & 6 & 7 & 8 & 9 & 10 & \\
\hline $\begin{array}{l}\text { 1. Access to the area } \\
1 \text { Open access } \\
10 \text { ISA-controlled access }\end{array}$ & Property rights & $1^{*}$ & 2 & 5 & 13 & 10 & 2 & 1 & 1 & 7 & 107 & 4.9 \\
\hline $\begin{array}{l}\text { 2. Exploitation of the area } \\
1 \text { First come, first served } \\
10 \text { Direct exploitation } \\
\text { by ISA }\end{array}$ & Property rights & $5^{*}$ & 0 & 7 & 2 & 5 & 4 & 13 & 112 & 1 & 0 & 8.9 \\
\hline $\begin{array}{l}\text { 3. Scientific research } \\
1 \text { Open access } \\
\text { 10 Research by ISA }\end{array}$ & Property rights & $7^{*}$ & 6 & 11 & 6 & 2 & 6 & 12 & 8 & 14 & 77 & 3.7 \\
\hline $\begin{array}{l}\text { 4. Production controls } \\
1 \text { Free market } \\
10 \text { Protect P/D }\end{array}$ & Price regulation & $2^{*}$ & 4 & 2 & 2 & 1 & 1 & 2 & 7 & 12 & 116 & 1.5 \\
\hline $\begin{array}{l}\text { 5. Revenue sources } \\
1 \text { Modest fees only } \\
10 \text { Substantial } \\
\text { production fees }\end{array}$ & $\begin{array}{l}\text { Benefit } \\
\text { redistribution }\end{array}$ & $8^{*}$ & 0 & 0 & 3 & 2 & 0 & 0 & 0 & 2 & 134 & 0.8 \\
\hline $\begin{array}{l}\text { 6. Revenue distribution } \\
1 \text { Strictly equal } \\
\text { distribution } \\
10 \text { Favor land-producing }\end{array}$ & $\begin{array}{l}\text { Benefit } \\
\text { redistribution } \\
\text { D }\end{array}$ & 9* & 6 & 20 & 30 & 13 & 11 & 13 & 20 & 8 & 19 & 0.7 \\
\hline
\end{tabular}

NOTE: $\mathrm{P}$ = land-based producers; $\mathrm{D}$ = developing countries; * = status quo; ISA = International Seabed Authority.

gates expressing "national interests" (Ikenberry, Lake, and Mastanduno 1988, 1). Delegates' positions are derived from their statements on policies during the second and third conference sessions in 1974 and 1975. Although this methodology has obvious limitations, we consider delegates' statements to be reasonable proxies for state positions because the point of data collection is prior to the substantive negotiations on seabed issues.

By and large, one third of the 51 identified policies are related to the problem of deep-sea mining. For the analysis of IS A rule making, 6 policies are of interest; all others have been either rather consensual or refer to the general guidelines of the convention such as rule enforcement, discretionary powers, and so on. Table 1 shows the distribution of preferred positions, ranging between 1 (not regulated) and 10 (highly regulated), as well as the mean salience $(m)$ for the 6 selected policies of the 149 states 
participating in UNCLOS III. ${ }^{5}$ According to our findings on states' salience, the most relevant questions have to do with property rights.

Three policies deal with the transfer of property rights. The first policy, concerning "access to the area," ranges from a claim for open access for all states (rank 1) to the position that the title to the area and its resources should be vested in a new international organization (rank 10). Typical for a policy with a polarized structure, we find a bimodal distribution of policy positions. A majority of 107 states preferred ISA-controlled access (rank 10), but a substantial minority favored open access with some limitations (rank 4). Only one state preferred the status quo with open access, which means that almost all states were interested in changing the status quo of the property rights but had different positions on the outcome. "Exploitation of the area" is another policy related to the question of who will have what kind of access to mineral resources. Proponents of a powerful international regime favored an international monopoly on mineral exploitation (rank 10), whereas opponents fought to provide exploitation rights to their national mining companies (rank 1). Again, most states wanted to change the status quo. One group favored some form of joint ventures between national miners, and another argued for national exploitation with mere registry or licensing function vested in the ISA. We also consider the policy "scientific research in the area" to be related to the question of ownership and user structure because research in the area is a necessary condition for mineral exploitation. Compared to the previous policies, the distribution is rather flat with three peaks atranks 3,7 , and 10 . The overall objective for modifying the status quo can be explained by the states' fear that open access to the area will lead to the income effects discussed above: a small number of major consumers and miners will profit, most states will not be able to benefit from the global commons, and land-based producers of those minerals will suffer losses.

For this reason, most states not only preferred a transition of property rights to the international regime but were also interested in provisions that limit the impact of seabed mining on the economies of land-based producers and redistribute the surplus expected from seabed resource use. Price regulation to limit their impact and benefit redistribution are thus two further topics that attracted considerable attention among

5. Preferences of states with respect to substantial policies are conceptualized as single-peaked preferences and obtained in five steps (Friedheim et al. 1977): in a first step, using thematic content analysis, statements of policy preference on single negotiating issues ("themes") by official state delegates are collected and coded. Second, themes representing different alternatives of one policy are grouped and scaled along a single dimension ranging from 1 to 10 . Third, country scores on each policy are calculated as means of a country's (different) remarks on that policy. In a fourth step, country scores have to be estimated for states that did not speak on that policy. To obtain estimated country scores, linear regression is performed with known country scores as dependent variables and 26 indices on geographic and economic characteristics as explanatory variables. Finally, a state's preferred position on a policy is calculated as a weighted average of its country score, if it exists, and its estimated country score. In this way, the number of remarks on which the country score is based serves as a weight for the country score, and the estimated score is given a weight of 1 . In addition, the relative frequency of remarks on a policy is used as a measure of the policies' salience to a country. In those cases in which there is no statement on a policy, salience is coded as 1 because we assume that the position of a state with no remarks on a certain policy has been represented by other delegates' statements rather than that the state has no interest in the policy in question. 
national delegates at the conference. Correspondingly, three policies are concerned with "production controls" ranging between policy options of the free market (rank 1) and protection of land-based producers by means of commodity agreements and production controls (rank 10); "revenue sources" ranging from no or modest fees (rank 1) to a considerable ISA budget financed by production fees and royalties (rank 10); and "revenue distribution," in which advocates of a North-South redistribution (rank 1) were opposed by states excluding benefit sharing with respect to states' different social and economic conditions ( (ank 10). Whereas the first and second policies were dominated by strong prointernational majorities with small status quo groups, the question of revenue distribution did not produce any discernible pattern of a distribution of positions.

In sum, we found that an overwhelming majority of 149 states preferred a change in the status quo. Only 32 of all 894 state positions on the six policies were in favor of maintaining the status quo, but in four of the six policies, a state majority even preferred the maximum deviation (rank 10) from the status quo (rank 1). This distribution of policy positions also shows that a consensus among all states would be difficult to achieve. The crucial question was whether an altering set of status quo supporters would allow for a mutual compensation. Figure 2 illustrates the location of states' positions on all six policies and of the status quo in a two-dimensional space. According to their similarities, three major and seven more specific clusters of states can be distinguished. The first major cluster consists of the 10 Western highly industrialized countries that are located close to the status quo. This cluster is completed by the USSR and Denmark, whereas Israel and Iceland as well as Canada, Czechoslovakia, Hungary, and Turkey belong to the second cluster of 18 smaller industrialized countries from the Western and Eastern hemispheres. The 113 developing countries form the third major cluster most distant from the status quo. We accordingly find different groups of state parties with different incentives to change the status quo.

To explain this configuration, the elementary direct impacts of deep-sea mining can be simulated by basic microeconomic models of metal markets for each actor. ${ }^{6}$ Theoretically, states' positions will be primarily determined by their income effects based on their role as consumers, land-based producers, and investors in mining technology. Although consumers and investors may expect gains from falling prices by future deep-sea mining, land-based producers of metals will be confronted with losses from falling prices and reduced market share. In addition, income effects may be produced by fees for deep-sea mining and redistribute revenues in the case of an institutionalized resource system. Consequently, states that are neither consumers nor investors only will benefit from the regime by fund-raising and/or redistributing production profits. Empirically, the major consumers and investors are indeed members of the first clus-

6. At the outset, the market is in equilibrium if the supply of land-based producers equals the demand of metal consumers. As a consequence of deep-sea mining, the additional supply of ocean production will shift the equilibrium in the long term. Metal prices will fall, the quantity supplied by land-based producers will be reduced, and a substantial amount will be replaced by cheaper metal from deep-sea mining (Wijkman 1981; Foders 1985). 


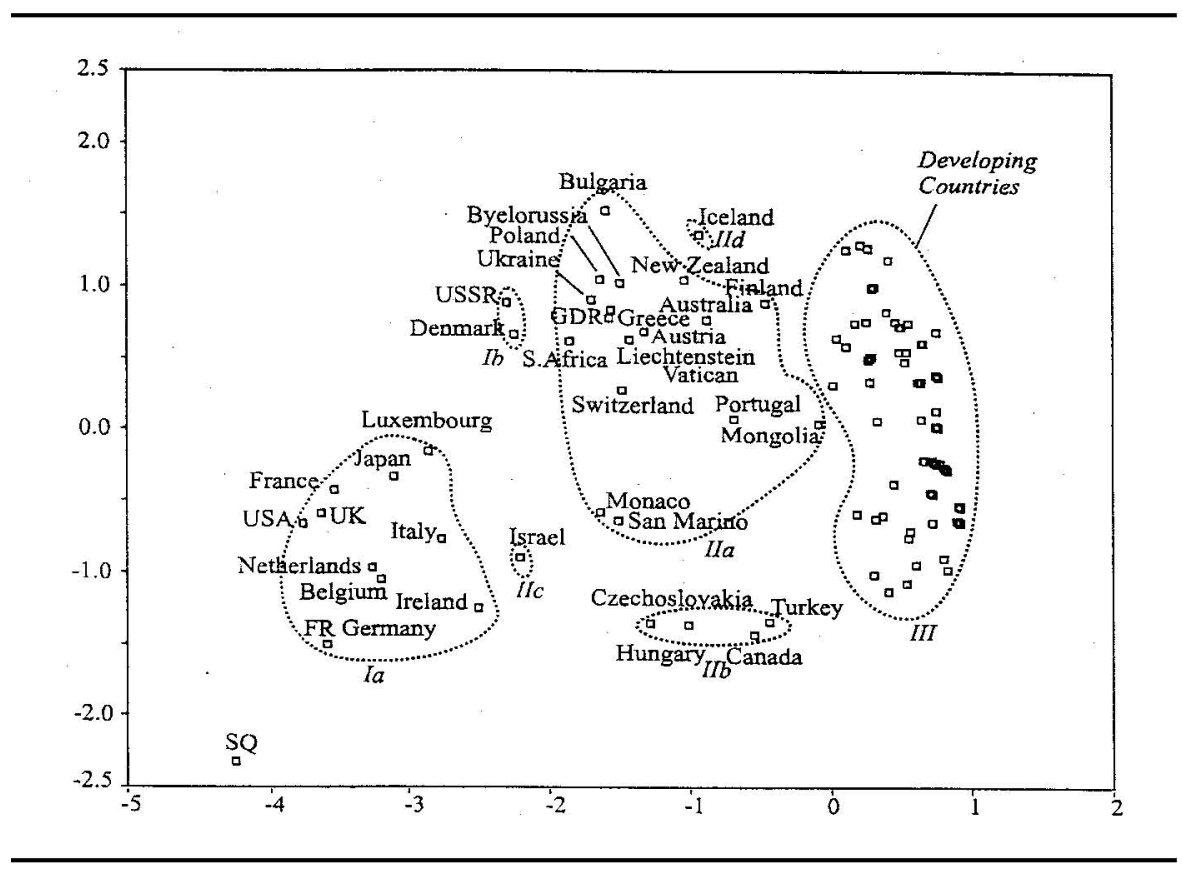




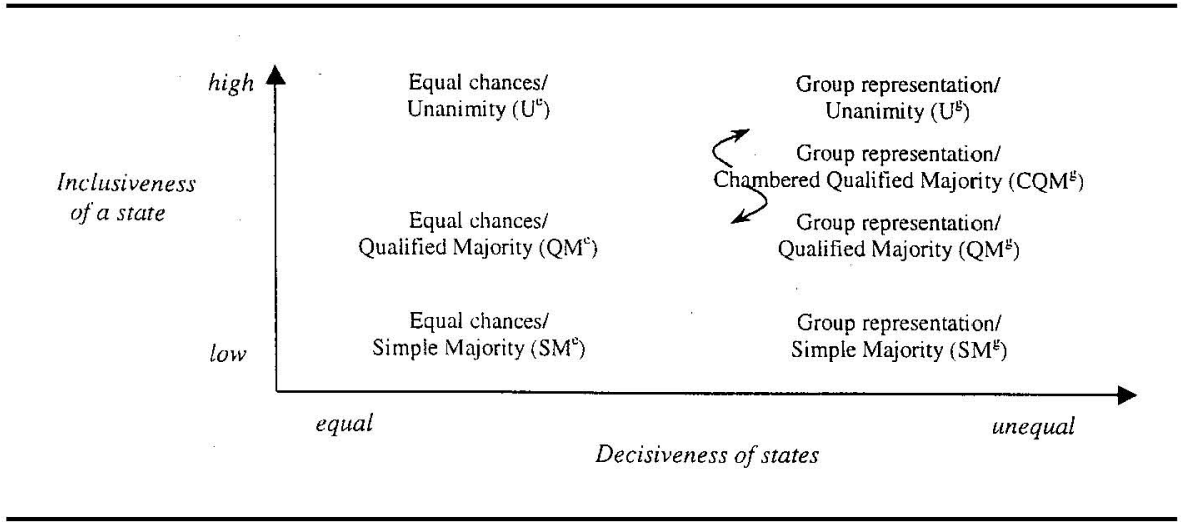

Figure 3: Characterization of Rules in the Council

\section{DECISION-MAKING RULES OF THE ISA COUNCIL}

Not surprisingly, the composition of the ISA council and its rules became the core constitutional question. Right from the beginning of UNCLOS III, most negotiators conceded that the council as the executive decision-making body should consist of a small number of states to guarantee the proper conduct of day-to-day activities. ${ }^{7}$ The proposal of a 36-member council was indeed uncontroversial, but the debate instead was about who should be represented in the voting body and how decisions should be made (Wolfrum 1984, 540 ff.; Dupuy and Vignes 1991, 733 ff.). In this respect, states had to agree on two central topics: first, they had to determine the appropriate voting quota in the council that defines the inclusiveness property. The principal alternatives were a high voting quota, which would guarantee state inclusiveness but increase the ISA gridlock danger, or a low voting quota, which would run the individual risk of being excluded but allow for more policy change by the ISA. The second important topic concerned whether every state should have the same voting rights or whether group representation should establish prerogatives for rather important states in the council. This distribution of decisiveness plays a role in future outcomes because prerogative voting rights increase a state's likelihood of determining the final decision. Figure 3 classifies six basic alternative rules by the two properties that refer to both topics: (1) inclusiveness and how to define a minimal number of states that can alter the status quo and (2) decisiveness and whether to differentiate between states by means of group representation.

Besides the six rules ranging between high, medium, and low inclusiveness as well as equal and unequal decisiveness, a seventh alternative of a multicameral voting pro-

7. Early plans for the International Seabed Authority (ISA) envisaged the assembly (as the plenary organ of the ISA representing all member states) to be the dominant decision-making body. In the 1982 convention, the assembly is described as the supreme organ, but this supremacy is merely formal, and the 1994 implementation agreement also stresses the preponderant role of the council (Dupuy and Vignes 1991, 696). 
cedure attracted major attention. According to this proposal, council members would be elected on the basis of group representation and decisions taken by a two-thirds majority of members, "provided that such decisions are not opposed by a majority in any one of the [four] chambers." of consumers, investors, and land-based producers, and the group of developing countries and the remaining 18 members of the council would be treated as a single fourth chamber. This multicameral qualified majority rule $\left(\mathrm{CQM}^{\mathrm{g}}\right)$ provides collective veto rights for distinct groups and thus gives higher inclusiveness and more decisiveness to the first three groups representing special economic interests (Wolfrum 1995, $312 \mathrm{ff}$.). It therefore provides a solution that is in between simple majority and unanimity but introduces prerogatives for certain states.

Taking account of these two properties, the legal status quo and states' positions on substantial policy dimensions, we next employ our model to delineate states' rule preferences from their policy positions. We determine the mean expected utility of each rule and their expected distributive effects and ask for a rule that satisfies the criterion of Pareto superiority. Following that, we take a closer look at states' rule preference orderings regarding the two properties of rules, inclusiveness and decisiveness.

\section{FINDINGS: CONSTITUTIONAL DISAGREEMENT ON THE CHOICE OF ISA RULES}

Why did some states oppose the 1982 convention, whereas most states accepted the proposed regime? To answer this question, we estimate states' expected benefits from decision making using an approximation formula of equation (1). ${ }^{9}$ For each policy with decision-making provision, we interpret the legal status quo as the UNCLOS III negotiations' "no-agreement point." Because we define the current setting as the reference point, we can calculate actors' expected utility from the negotiations' failure as their status quo utility $E U_{r e f, t}^{i}=U^{i}\left(s q_{t}\right)$. Consequently, we derive their expected surplus from a change of the current setting rather than their absolute expected gains under those rules:

$$
\Delta E U_{j, t}^{i}=E U_{j, t}^{i}-E U_{r e f, t}^{i}
$$

Hereby, actors' utilities from a policy $x$ are assumed to be linearly related to the distance of $x$ from actors' ideal points $x_{t}^{* i}$ and ranging from 0 (low) to 1 (high):

$$
U^{i}(x)=1-\frac{\left|x_{t}^{* i}-x\right|}{9}
$$

8. Implementation Agreement, Annex, Sec. 3, para. 5.

9. Because computing time is enormous, we have to approximate equation (1) assuming all coalitions to be equiprobable, that is, $\pi_{t}(S)=1 / 2^{n}$ forall coalitions $S$ and all issues $t$ (see appendix, equation $A 9$ ). For the case under study, estimation errors can be expected to be negligibly small: first, high voting quotas require large and thus similarcoalitions; second, homogeneous coalitions result from the majority-dominated distributions of policy positions. 
Table 2a summarizes our findings on states' expected utilities of council rules. The columns record mean values of expected benefits and Gini indices; the latter describe the distribution of those expected gains from future decision making. The columns of Table $2 b$ list the number of states with less, equal to, or greater surplus than zero for each of the seven council rules in question.

According to Table 2a, unanimity both with and without group representation seems to be unattractive because it restricts decision making to the unlikely consent of all 36 council members. ${ }^{10}$ Because policy change is nearly impossible under unanimity, there is no difference between the maintenance of the status quo and unanimous decision-making outcomes resulting in an expected net surplus against the status quo of 0 for all 149 actors. By contrast, on average, we observe a positive expected surplus for all policies and all majority rules, indicating that they offered a profitable change in the current status quo. In general, we find that the more states preferred policy change and the more distant the (respective) majority was from the status quo, the higher were the majorities' expected utilities from majority rules. Production controls and revenue sources are particular examples of such high mean utilities. Besides, we find that the less inclusive decision-making rules were, the more likely a status quo alteration was and the higher was the average expected utility. From this overall perspective, majority rules seem to be beneficial in general.

High mean utility, however, is a rather debatable criterion for getting the required consent of all states. Rational actors instead are often assumed to agree only to those alternatives that are Pareto superior to the status quo and, possibly, also to consider whether the overall distribution meets specific conditions such as equality or fairness. We therefore list Gini indices ranging from 0 to 1 to indicate the degree of inequality in the distribution of expected utilities. ${ }^{11}$ Empirically, there was little difference between rules that only differ regarding simple or qualified majority provisions, but the differences between the two rules for representing states in the council were apparent. For any policy, state group representation in the ISA's dominant decision-making body was more suitable to generate a rather even distribution of expected utilities. That is, not the "one state, one vote" principle but the allocation of privileges for certain states promised a distribution of future gains that would better meet the equality concept.

Table $2 \mathrm{~b}$ shows that, on average, between 134 and 136 states preferred both simple and qualified majority voting to the status quo of no institutionalization of the deep

10. To simulate group representation, those 21 states have been selected as major consumers of deep-sea minerals (C) whose 1974-1975 consumption of minerals sums up to half of the world's total consumption (in value terms). The set of major land-based producers (P) is similarly defined ( 22 states). Based on economic and technological characteristics for 1974-1975,20 states have been identified as potential seabed investors and mining states (I). The group of developing countries (D) consists of all states that in 1974- 1975 received development aid from other countries or international funds. Obviously, interest groups of states are not exclusive: two states are CIPD, 9 CIP, $1 \mathrm{IPD}, 7 \mathrm{CI}, 2 \mathrm{CP}, 8 \mathrm{PD}, 1 \mathrm{C}, 1 \mathrm{I}, 1 \mathrm{P}, 89 \mathrm{D}$. "Others" groups all states belonging to none of the four economic groups.

11. The Gini index can be written as $g=1+\frac{1}{n}-2 \frac{q_{1}+2 q_{2}+\cdots n q_{n}}{n^{2} Q}$, where $Q$ is the mean utility and states 1 to $n$ have utilities $q_{1}$ to $q_{n}$ (Sugden 1981, 62). 
TABLE 2

Expected Surplus of Council Rules

\begin{tabular}{|c|c|c|c|c|c|c|c|c|c|c|c|c|c|c|}
\hline & \multicolumn{6}{|c|}{ Equal Chances } & \multicolumn{8}{|c|}{ Group Representation } \\
\hline & \multicolumn{2}{|c|}{$\begin{array}{l}\text { Simple } \\
\text { Majority }\end{array}$} & \multicolumn{2}{|c|}{$\begin{array}{l}\text { Qualified } \\
\text { Majority }\end{array}$} & \multicolumn{2}{|c|}{ Unanimity } & \multicolumn{2}{|c|}{$\begin{array}{l}\text { Simple } \\
\text { Majority }\end{array}$} & \multicolumn{2}{|c|}{$\begin{array}{l}\text { Qualified } \\
\text { Majority }\end{array}$} & \multicolumn{2}{|c|}{$\begin{array}{c}\text { Chambered } \\
\text { Qualified Majority }\end{array}$} & \multicolumn{2}{|c|}{ Unanimity } \\
\hline & Mean & $\begin{array}{l}\text { Gini } \\
\text { Index }\end{array}$ & Mean & $\begin{array}{l}\text { Gini } \\
\text { Index }\end{array}$ & Mean & $\begin{array}{l}\text { Gini } \\
\text { Index }\end{array}$ & Mean & $\begin{array}{l}\text { Gini } \\
\text { Index }\end{array}$ & Mean & $\begin{array}{l}\text { Gini } \\
\text { Index }\end{array}$ & Mean & $\begin{array}{l}\text { Gini } \\
\text { Index }\end{array}$ & Mean & $\begin{array}{l}\text { Gini } \\
\text { Index }\end{array}$ \\
\hline \multicolumn{15}{|l|}{ a. Expected surplus $\Delta E U_{j}^{i}$} \\
\hline 1. Access to the area & .2683 & .2976 & .0201 & 2976 & 0 & $\ldots$ & .2589 & .2833 & .0194 & .2835 & .0149 & 2848 & 0 & $\ldots$ \\
\hline 2. Exploitation of the area & 2488 & .1892 & .0187 & 1893 & 0 & $\ldots$ & .2405 & .1750 & .0181 & .1752 & .0137 & .1755 & 0 & $\ldots$ \\
\hline 3. Scientific research in the area & .2088 & .4493 & .0157 & 4496 & 0 & $\ldots$ & .2020 & .4169 & .0152 & .4174 & .0116 & .4193 & 0 & $\ldots$ \\
\hline 4. Production controls & .3368 & .1594 & .0253 & .1594 & 0 & $\ldots$ & .3273 & .1499 & .0246 & .1500 & .0187 & .1503 & 0 & $\ldots$ \\
\hline 5. Revenue sources & .3452 & .1542 & .0259 & .1542 & 0 & $\ldots$ & .3289 & .1511 & .0247 & .1511 & .0188 & .1512 & 0 & $\ldots$ \\
\hline 6. Revenue distribution & .1108 & .6470 & .0083 & .6494 & 0 & $\ldots$ & .1108 & .6465 & .0083 & .6494 & .0063 & .6588 & 0 & $\ldots$ \\
\hline \multirow[t]{2}{*}{ All policies ${ }^{a}$} & .2519 & .2435 & .0189 & .2435 & 0 & $\ldots$ & .2431 & .2311 & .0183 & .2313 & .0139 & .2322 & 0 & $\ldots$ \\
\hline & - & 0 & - & + & 0 & + & 0 & + & + & - & 0 & - & 0 & + \\
\hline
\end{tabular}

b. Number of states with negative

$(-)$, no $(0)$, or positive $(+)$

expected surplus $\Delta E U_{j}^{i}$

1. Access to the area
2. Exploitation of the area

$\begin{array}{lllllllllllllllllllll}21 & 0 & 128 & 21 & 0 & 128 & 0 & 149 & 0 & 21 & 0 & 128 & 21 & 0 & 128 & 21 & 0 & 128 & 0 & 149 & 0\end{array}$

3. Scientific reserch

4. Production controls
5. Revenue sources

$\begin{array}{lllllllllllllllllllll}14 & 0 & 135 & 14 & 0 & 135 & 0 & 149 & 0 & 12 & 0 & 137 & 12 & 0 & 137 & 12 & 0 & 137 & 0 & 149 & 0\end{array}$

$\begin{array}{lllllllllllllllllllll}30 & 0 & 119 & 30 & 0 & 119 & 0 & 149 & 0 & 30 & 0 & 119 & 30 & 0 & 119 & 30 & 0 & 119 & 0 & 149 & 0\end{array}$

6. Revenue distribution

$\begin{array}{llllllllllllllllllllll}11 & 0 & 138 & 11 & 0 & 138 & 0 & 149 & 0 & 10 & 0 & 139 & 10 & 0 & 139 & 10 & 0 & 139 & 0 & 149 & 0\end{array}$

$\begin{array}{lllllllllllllllllllllllll} & 35 & 0 & 114 & 35 & 0 & 114 & 0 & 149 & 0 & 35 & 0 & 114 & 35 & 0 & 114 & 35 & 0 & 114 & 0 & 149 & 0\end{array}$

$\begin{array}{llllllllllllllllllllll}\text { All policies }^{2} & 15 & 0 & 134 & 15 & 0 & 134 & 0 & 149 & 0 & 13 & 0 & 136 & 13 & 1 & 135 & 13 & 1 & 135 & 0 & 149 & 0\end{array}$

a. $\Delta E U_{j}^{i}=\sum_{i=1}^{b} s_{t}^{i}\left(E U_{j, t}^{i}-E U_{r e f, t}^{i}\right)$, where $s_{t}^{i}$ is $i$ 's salience regarding issue $t$. 
seabed. They could expect to gain from a council's greater capacity to act under majority rules. Their common dislike for the status quo increased the likelihood of outcomes that included their own positions so that any change in the current setting would have been Pareto superior for them. With regard to each policy and each rule, between 10 and 35 states, however, had to expect no gains from any institutionalization. The last row of Table $2 \mathrm{~b}$ indicates that these states had to fear being permanently out voted, even though they might agree on rules when expecting (small) losses with some decisions but substantial gains with others. Summing up states' expected gains and losses over all policies reveals that 13 to 15 states would have losses when one of the majority rules was applied to all six policies. And in fact, on taking a closer look at this set, we find all states that rejected the Convention on the Law of the Sea in 1982. Eleven of the 15 states with expected losses voted against or abstained: Belgium, Bulgaria, the Federal Republic of Germany, German Democratic Republic, Italy, Luxembourg, the Netherlands, Ukraine, Soviet Union, the United Kingdom, and the United States. Because 124 states with expected surpluses indeed voted in favor of the convention, we correctly predicted the attitude of $91 \%$ of all possible parties to the first agreement. ${ }^{12}$

But if net benefits were not achievable for some states under any rule, why did these states finally accept the new ocean regime after renegotiation and modification of the convention? The implementation agreement embodied most of the changes in the ISA regime sought by the disgruntled industrialized countries. This included a more market-orientated usage of the resources, less ISA power to limit seabed production in attempts to protect land-based mining, and the reduction of mining fees. Besides these modifications in the regime alignment, the implementation agreement incorporated major changes in the decision-making rules and, in doing so, the conditions under which the principal regime alignment will be translated into day-to-day substantial policy making. But how can these modifications in the rules be explained?

Two exogenous reasons are conceivable for their final approval: first, states' views on seabed mining substantially changed from the time of our data collection date in 1975 to their agreement in 1990. For the purpose of analysis, such a change in states' policy positions would simply conclude with measurement problems of actors' preferences and call for new data collection to depict states' ex ante views at the beginning of the informal consultations. Second, a changing legal status quo of the deep sea or social norms of the international community have led these states to accept the regime. Indeed, several developments in the late 1980s made a renegotiation and multilateral agreement of global scope more desirable and more likely.

In addition to events such as the new sympathy of the U.S. (Clinton) administration toward a universal law of the sea, which should not affect other states' policy positions

12. Four states are predicted to have a negative surplus but voted in favor: Denmark, France, Ireland, and Japan. Ten states have a positive surplus but voted negatively or abstained: Byelorussia, Czechoslovakia, Israel, Turkey, Venezuela, Mongolia, Poland, Spain, Thailand, and Hungary (Brown 1994, 11). Moreover, as of the approval of the implementation agreement, none of the states with predicted negative surplus had ratified, acceded, or succeeded to the convention (Larson, Roth, and Selig 1995, 297-98). 
at all, two circumstances are especially important for our assessment of states' expected benefits (Joyner 1996, 50-58). First, whereas earlier studies had projected a bonanza for commercializing mineral resources, market prices for the minerals in question had fallen, putting the profitability of deep-sea mining into question. Second, because the collapse of world socialism discredited the economic philosophy of the new international economic order against free-market principles, high stakes perceived by the North and South diminished. Neither reason should have changed states' positions but certainly affected their salience and thereby reduced states' absolute expected profits from deep-sea mining and the relative importance of Part XI in relation to the convention as a whole. Because our methodology is concerned with rule making, however, we cannot weigh gains from the convention as a whole against expected gains from decision making within the ISA. The assessment of the industrialized states' overall gains to compensate for the (unfavorable) seabed regime is beyond the scope of our study.

Instead, we want to discuss endogenous reasons that might have aided in achieving a compromise - that is, rules that, assuming that losses are compensated, are acceptable for both winners and losers. Table 3 lists the predicted rule preferences of states regarding the six seabed mining policies. Column 2 shows alternative preference rankings of rules; columns 3 and 4 indicate how many and which sort of states have these orderings. On every policy, a strong majority of about 120 states should prefer simple majority and rank unanimity as their less favored option, whereas the preference ordering of about 20 states should be the reverse. Not surprisingly, the former set mainly consists of developing countries and land-based producers (half of which are developing countries), whereas major consumers and investors are more often in the latter set. When comparing equal to unequal settings, we find that in most cases, developing countries and land-based producers preferred equal chances for states to take a seat in the council, but consumers and investors favored group representation. Even though none of them were in favor of a two-thirds majority provision (with or without group representation), neither disliked this rule the most. In this respect, the qualified majority rule was a possible compromise between the two camps of developing countries and land-based producers, on one hand, and major consumers and investors, on the other.

Figure 4 illustrates the space of alternative ISA rules using a two-dimensional unfolding of the corresponding states' preferences. The proximity of small industrialized countries and $\mathrm{SM}^{\mathrm{g}}$, for instance, indicates that, on average, both preferred simple majority voting with group representation to any other rule. The two-dimensional unfolding also reveals the impacts of alternative rules when locating rules on the horizontal axis according to their inclusiveness and on the vertical axis according to their equal or unequal decisiveness. Eleven of the major industrialized states are far from the majority of the international community but close to the council rule of unanimity, whereas 109 states, most of them developing countries, favored simple majority voting with equal chances for states to have a seat in the council. In fact, the chambered majority rule was a possible compromise that is at least as close to the major industrialized 
TABLE 3

Preferences on Council Rules

\begin{tabular}{|c|c|c|}
\hline \multirow{2}{*}{$\begin{array}{l}\text { Policy/Preference Ordering }^{\mathrm{a}} \\
\text { 1. } \mathrm{SM}^{\mathrm{e}}>\mathrm{SM}^{\mathrm{g}}>\mathrm{QM}^{\mathrm{e}}>\mathrm{QM}^{\mathrm{g}}>\mathrm{CQM}^{\mathrm{g}}>\mathrm{U}^{\mathrm{e}}=\mathrm{U}^{\mathrm{g}}\end{array}$} & \multicolumn{2}{|r|}{ Number of States (according to economic groups ${ }^{b}$ ) } \\
\hline & 114 & $\begin{array}{l}2 \mathrm{CIPD}, 1 \mathrm{CIP}, 1 \mathrm{PD}, 2 \mathrm{CI}, 1 \mathrm{CP}, 8 \mathrm{PD}, 1 \mathrm{C} \text {, } \\
88 \mathrm{D}, 10 \mathrm{O}\end{array}$ \\
\hline $\mathrm{U}^{\mathrm{e}}=\mathrm{U}^{\mathrm{g}}>\mathrm{CQM}^{\mathrm{g}}>\mathrm{QM}^{\mathrm{g}}>\mathrm{QM}^{\mathrm{e}}>\mathrm{SM}^{\mathrm{g}}>\mathrm{SM}^{\mathrm{e}}$ & 21 & $5 \mathrm{CIP}, 3 \mathrm{CI}, 1 \mathrm{CP}, 1 \mathrm{D}, 11 \mathrm{O}$ \\
\hline $\mathrm{SM}^{\mathrm{g}}>\mathrm{SM}^{\mathrm{e}}>\mathrm{CQM}^{\mathrm{g}}>\mathrm{QM}^{\mathrm{e}}>\mathrm{QM}^{\mathrm{g}}>\mathrm{U}^{\mathrm{e}}=\mathrm{U}^{\mathrm{g}}$ & 10 & $3 \mathrm{CIP}, 2 \mathrm{CI}, 1 \mathrm{I}, 4 \mathrm{O}$ \\
\hline $\mathrm{SM}^{\mathrm{g}}>\mathrm{SM}^{\mathrm{e}}>\mathrm{QM}^{\mathrm{g}}>\mathrm{QM}^{\mathrm{e}}>\mathrm{CQM}^{\mathrm{g}}>\mathrm{U}^{\mathrm{e}}=\mathrm{U}^{\mathrm{g}}$ & 4 & 40 \\
\hline 2. $\mathrm{SM}^{\mathrm{e}}>\mathrm{SM}^{\mathrm{g}}>\mathrm{QM}^{\mathrm{e}}>\mathrm{QM}^{\mathrm{g}}>\mathrm{CQM}^{\mathrm{g}}>\mathrm{U}^{\mathrm{e}}=\mathrm{U}^{\mathrm{g}}$ & 112 & $\begin{array}{l}2 \mathrm{CIPD}, 1 \mathrm{CIP}, 1 \mathrm{IPD}, 2 \mathrm{CI}, 1 \mathrm{CP}, 8 \mathrm{PD}, 86 \mathrm{D} \text {, } \\
11 \mathrm{O}\end{array}$ \\
\hline $\mathrm{SM}^{\mathrm{g}}>\mathrm{SM}^{\mathrm{e}}>\mathrm{QM}^{\mathrm{g}}>\mathrm{QM}^{e}>\mathrm{CQM}^{\mathrm{g}}>\mathrm{U}^{e}=\mathrm{U}^{\mathrm{g}}$ & 22 & $3 \mathrm{CIP}, 2 \mathrm{CI}, 1 \mathrm{CP}, 1 \mathrm{C}, 2 \mathrm{D}, 13 \mathrm{O}$ \\
\hline $\mathrm{U}^{\mathrm{e}}=\mathrm{U}^{\mathrm{g}}>\mathrm{CQM}^{\mathrm{g}}>\mathrm{QM}^{\mathrm{g}}>\mathrm{QM}^{\mathrm{e}}>\mathrm{SM}^{\mathrm{g}}>\mathrm{SM}^{\mathrm{e}}$ & 12 & $5 \mathrm{CIP}, 3 \mathrm{CI}, 1 \mathrm{I}, 3 \mathrm{O}$ \\
\hline $\mathrm{SM}^{\mathrm{g}}>\mathrm{QM}^{\mathrm{g}}=\mathrm{CQM}^{\mathrm{g}}=\mathrm{U}^{\mathrm{e}}=\mathrm{U}^{\mathrm{g}}>\mathrm{QM}^{\mathrm{e}}>\mathrm{SM}^{\mathrm{e}}$ & 2 & 20 \\
\hline $\mathrm{SM}^{\mathrm{e}}>\mathrm{SM}^{\mathrm{g}}>\mathrm{QM}^{\mathrm{g}}>\mathrm{QM}^{e}>\mathrm{CQM}^{\mathrm{g}}>\mathrm{U}^{\mathrm{e}}=\mathrm{U}^{\mathrm{g}}$ & 1 & $1 \mathrm{D}$ \\
\hline 3. $\mathrm{SM}^{\mathrm{e}}>\mathrm{SM}^{\mathrm{g}}>\mathrm{QM}^{\mathrm{e}}>\mathrm{QM}^{\mathrm{g}}>\mathrm{CQM}^{\mathrm{g}}>\mathrm{U}^{\mathrm{e}}=\mathrm{U}^{\mathrm{g}}$ & 99 & $\begin{array}{l}2 \mathrm{CIPD}, 1 \mathrm{CIP}, 1 \mathrm{IPD}, 1 \mathrm{CI}, 1 \mathrm{CP}, 6 \mathrm{PD}, 1 \mathrm{C} \\
77 \mathrm{D}, 9 \mathrm{O}\end{array}$ \\
\hline $\mathrm{U}^{\mathrm{e}}=\mathrm{U}^{\mathrm{g}}>\mathrm{CQM}^{\mathrm{g}}>\mathrm{QM}^{\mathrm{g}}>\mathrm{QM}^{\mathrm{e}}>\mathrm{SM}^{\mathrm{g}}>\mathrm{SM}^{\mathrm{e}}$ & 24 & $6 \mathrm{CIP}, 3 \mathrm{CI}, 1 \mathrm{CP}, 1 \mathrm{I}, 1 \mathrm{D}, 12 \mathrm{O}$ \\
\hline $\mathrm{SM}^{\mathrm{g}}>\mathrm{SM}^{\mathrm{e}}>\mathrm{QM}^{\mathrm{g}}>\mathrm{QM}^{\mathrm{e}}>\mathrm{CQM}^{\mathrm{g}}>\mathrm{U}^{\mathrm{e}}=\mathrm{U}^{\mathrm{g}}$ & 18 & $2 \mathrm{CIP}, 1 \mathrm{CI}, 2 \mathrm{PD}, 11 \mathrm{D}, 2 \mathrm{O}$ \\
\hline $\mathrm{U}^{\mathrm{e}}=\mathrm{U}^{\mathrm{g}}>\mathrm{QM}^{\mathrm{g}}>\mathrm{CQM}^{\mathrm{g}}>\mathrm{QM}^{\mathrm{e}}>\mathrm{SM}^{\mathrm{g}}>\mathrm{SM}^{\mathrm{e}}$ & 6 & $2 \mathrm{CI}, 4 \mathrm{O}$ \\
\hline $\mathrm{SM}^{\mathrm{g}}>\mathrm{SM}^{\mathrm{e}}>\mathrm{CQM}^{\mathrm{g}}>\mathrm{QM}^{\mathrm{e}}>\mathrm{QM}^{\mathrm{g}}>\mathrm{U}^{\mathrm{e}}=\mathrm{U}^{\mathrm{g}}$ & 2 & 20 \\
\hline 4. $\mathrm{SM}^{\mathrm{e}}>\mathrm{SM}^{\mathrm{g}}>\mathrm{QM}^{\mathrm{e}}>\mathrm{QM}^{\mathrm{g}}>\mathrm{CQM}^{\mathrm{g}}>\mathrm{U}^{\mathrm{e}}=\mathrm{U}^{\mathrm{g}}$ & 116 & $2 \mathrm{CIPD}, 4 \mathrm{CP}, 4 \mathrm{CI}, 1 \mathrm{CP}, 8 \mathrm{PD}, 1 \mathrm{C}, 80 \mathrm{D}, 16 \mathrm{O}$ \\
\hline $\mathrm{SM}^{\mathrm{g}}>\mathrm{SM}^{\mathrm{e}}>\mathrm{QM}^{\mathrm{g}}>\mathrm{QM}^{\mathrm{e}}>\mathrm{CQM}^{\mathrm{g}}>\mathrm{U}^{\mathrm{e}}=\mathrm{U}^{\mathrm{g}}$ & 22 & $1 \mathrm{CIP}, 1 \mathrm{IPD}, 1 \mathrm{CP}, 8 \mathrm{D}, 11 \mathrm{O}$ \\
\hline $\mathrm{U}^{\mathrm{e}}=\mathrm{U}^{\mathrm{g}}>\mathrm{CQM}^{\mathrm{g}}>\mathrm{QM}^{\mathrm{g}}>\mathrm{QM}^{\mathrm{e}}>\mathrm{SM}^{\mathrm{g}}>\mathrm{SM}^{\mathrm{e}}$ & 10 & $4 \mathrm{CIP}, 3 \mathrm{CI}, 1 \mathrm{I}, 2 \mathrm{O}$ \\
\hline $\mathrm{SM}^{\mathrm{g}}>\mathrm{QM}^{\mathrm{g}}=\mathrm{CQM}^{\mathrm{g}}=\mathrm{U}^{\mathrm{e}}=\mathrm{U}^{\mathrm{g}}>\mathrm{QM}^{\mathrm{e}}>\mathrm{SM}^{\mathrm{e}}$ & 1 & $1 \mathrm{D}$ \\
\hline 5. $\mathrm{SM}^{\mathrm{e}}>\mathrm{SM}^{\mathrm{g}}>\mathrm{QM}^{\mathrm{e}}>\mathrm{QM}^{\mathrm{g}}>\mathrm{CQM}^{\mathrm{g}}>\mathrm{U}^{\mathrm{e}}=\mathrm{U}^{\mathrm{g}}$ & 134 & $\begin{array}{l}2 \mathrm{CIPD}, 4 \mathrm{CIP}, 1 \mathrm{IPD}, 4 \mathrm{CI}, 2 \mathrm{CP}, 8 \mathrm{PD}, 87 \mathrm{D}, \\
1 \mathrm{C}, 25 \mathrm{O}\end{array}$ \\
\hline $\mathrm{U}^{\mathrm{e}}=\mathrm{U}^{\mathrm{g}}>\mathrm{CQM}^{\mathrm{g}}>\mathrm{QM}^{\mathrm{g}}>\mathrm{QM}^{\mathrm{e}}>\mathrm{SM}^{\mathrm{g}}>\mathrm{SM}^{\mathrm{e}}$ & 11 & $5 \mathrm{CIP}, 3 \mathrm{CI}, 1 \mathrm{I}, 2 \mathrm{O}$ \\
\hline $\mathrm{SM}^{\mathrm{g}}>\mathrm{SM}^{\mathrm{e}}>\mathrm{QM}^{\mathrm{g}}>\mathrm{QM}^{\mathrm{e}}>\mathrm{CQM}^{\mathrm{g}}>\mathrm{U}^{\mathrm{e}}=\mathrm{U}^{\mathrm{g}}$ & 4 & $2 \mathrm{D}, 2 \mathrm{O}$ \\
\hline 6. $\mathrm{SM}^{\mathrm{e}}=\mathrm{SM}^{\mathrm{g}}>\mathrm{QM}^{\mathrm{g}}>\mathrm{QM}^{\mathrm{e}}>\mathrm{CQM}^{\mathrm{g}}>\mathrm{U}^{\mathrm{e}}=\mathrm{U}^{\mathrm{g}}$ & 114 & $\begin{array}{l}2 \mathrm{CIPD}, 6 \mathrm{CIP}, 1 \mathrm{IPD}, 7 \mathrm{CI}, 2 \mathrm{CP}, 4 \mathrm{PD}, 1 \mathrm{C} \\
1 \mathrm{I}, 73 \mathrm{D}, 17 \mathrm{O}\end{array}$ \\
\hline $\mathrm{U}^{\mathrm{e}}=\mathrm{U}^{\mathrm{g}}>\mathrm{QM}^{\mathrm{g}}>\mathrm{CQM}^{\mathrm{g}}>\mathrm{QM}^{\mathrm{e}}>\mathrm{SM}^{\mathrm{g}}>\mathrm{SM}^{\mathrm{e}}$ & 20 & $2 \mathrm{CIP}, 2 \mathrm{PD}, 10 \mathrm{D}, 6 \mathrm{O}$ \\
\hline $\mathrm{U}^{\mathrm{e}}=\mathrm{U}^{\mathrm{g}}>\mathrm{CQM}^{\mathrm{g}}>\mathrm{QM}^{\mathrm{g}}>\mathrm{QM}^{\mathrm{e}}>\mathrm{SM}^{\mathrm{e}}>\mathrm{SM}^{\mathrm{g}}$ & 15 & $1 \mathrm{CIP}, 2 \mathrm{PD}, 6 \mathrm{D}, 6 \mathrm{O}$ \\
\hline
\end{tabular}

a. $a>b=$ actor prefers $a$ to $b ; a=b=$ actor is indifferent between $a$ and $b$.

b. $\mathrm{C}=$ consumer; $\mathrm{I}=$ investor, $\mathrm{P}=$ land-producer; $\mathrm{D}=$ developing country; $\mathrm{O}=$ other.

states' positions as the 1982 convention's provisions for unanimity and qualified majority voting with group representation.

In particular, because the latter have gained from group representation in the ISA council and the implementation agreement's provision for a chambered qualified majority rule, consumers and investors indeed have profited from renegotiating Part $\mathrm{XI}$. The multicameral majority rule was the greatest possible concession to a minorities' rule preferences - without falling back on unanimity that actually would have constituted gridlock in the ISA's decision making. 


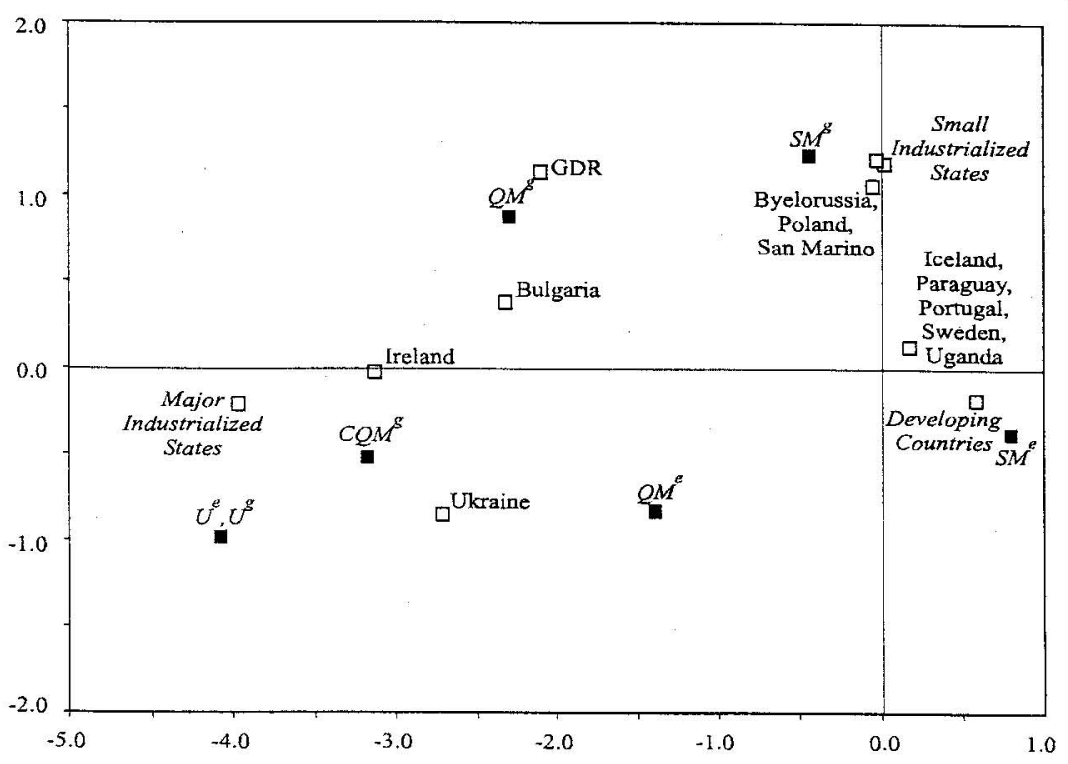

Figure 4: Spatial Location of States and Council Rules

NOTE: Two-dimensional unfolding of states' preferences orderings over seven council rules (Euclidian model), S-stress = 0.119. Major industrialized states: Belgium, Denmark, FR Germany, France, Italy, Japan, Luxembourg, Netherlands, United Kingdom, United States, Soviet Union. Small industrialized states: Australia, Austria, Canada, Czechoslovakia, Finland, Greece, Vatican, Hungary, Israel, Liechtenstein, Monaco, Mongolia, New Zealand, Turkey, South Africa, Switzerland. Developing countries: Afghanistan, Albania, Algeria, Argentina, Bahamas, Bahrain, Bangladesh, Barbados, Bhutan, Bolivia, Botswana, Brazil, Burma, Burundi, Central African Republic, Cambodia, Cameroon, Chad, Chile, China, Colombia, Congo, Costa Rica, Cuba, Cyprus, Dahomey, Dominican Republic, Ecuador, El Salvador, Equatorial Guinea, Ethiopia, Fiji, Gabon, Gambia, Ghana, Guatemala, Guinea, Guinea-Bissau, Guyana, Haiti, Honduras, India, Indonesia, Iran, Iraq, Ivory Coast, Jamaica, Jordan, Kenya, Korea (North), Korea (South), Kuwait, Laos, Lebanon, Lesotho, Liberia, Libya, Madagascar, Malawi, Malaysia, Maldive Island, Mali, Malta, Mauritania, Mauritius, Mexico, Morocco, Nauru, Nepal, Nicaragua, Niger, Nigeria, Norway, Oman, Pakistan, Panama, Peru, Philippines, Qatar, Romania, Rwanda, Saudi Arabia, Senegal, Sierra Leone, Singapore, Somalia, Southern Yemen, Spain, Sri Lanka, Sudan, Swaziland, Syria, Tanzania, Thailand, Togo, Tonga, Trinidad and Tobago, Tunisia, United Arabian Emirate, United Arabian Republic, Upper Volta, Uruguay, Venezuela, Vietnam (North), Vietnam (South), Western Samoa, Yemen, Yugoslavia, Zaire, and Zambia.

\section{CONCLUSION: FROM RULE PREFERENCES TO CONSTITUTIONAL CHOICE?}

The ISA began its substantive work right after the convention, and the provisional application of the implementation agreement went into effect on November 16, 1994. Compared to other international regimes administering global commons, the ISA is 
vested not only with regulatory and managerial powers but also performs commercial and industrial activities and has profit-making goals when engaged in deep-sea mining. Most international financial/resource management institutions provide "international public services," but the ISA distributes natural resources and is directly involved in market activities that may have a major impact on national economies (Dupuy and Vignes 1991, 728). Several innovative constitutional features have thus been considered, such as supplementing the sovereign equality of states by representing groups with special economic and commercial interests and establishing a multichamber rule based on the idea of minority veto. Although these features themselves are not unique, they are innovative regarding international governance, which ranges from production control and revenue distribution to participating in commodity arrangements, and may serve as a model for institutionalizing the use of global commons with direct and extensive economic implications (Wolfrum 1995, 326).

The findings on the choice of ISA rules reveal that we are able to predict correctly the failure of the 1982 configuration. We observed that the more states preferred policy change, and the more distant the (respective) majority was from the status quo, the higher were the majorities' expected utilities from majority rules. Our results also show that not the "one state, one vote" principle but the allocation of privileges for certain states promised a distribution of future gains that would better meet the equality concept. And we also found evidence for the creation of a multicameral rule when taking a closer look at the spatial configuration of states' policy positions and the location of the legal status quo. States' positions almost reflect their status as being a producer, consumer, investor, or developing country, the latter having higher incentives to establish the regime.

However, our model on the formation of rule preferences overestimates rather extreme rules: for all policies, we predict that most states will prefer simple majority voting and that a substantial minority will favor unanimity, but 146 states actually stated that they would prefer a two-thirds majority rule with either equal or group representation. There are three possible reasons for this shortcoming. First, the model does not adequately reflect the council's capacity to act under extreme rules. Second, the model does not sufficiently reflect the states' perceptions of the council's capacity to act. Third, the model adequately predicts states' rule preferences, but we have problems measuring policy positions. The first two cases call our model into question, but the last reason is supported by the fact that the 1982 convention provided for unanimity for some policies, and the 1994 implementation agreement introduced the two-thirds majority rule with group veto rights.

By and large, we argue that former approaches to international institutionalization have underspecified the problem of constitutional choice by disregarding the difference between policy positions and preferences on rules. In our view, the study of the formation of rule preferences gives a realistic insight into problems of constitutional choice. In this regard, our expected utility model puts the three components of constitutional choice together: actors' future policy positions, the working properties of institutions, and future incentives for and constraints to decision making (i.e., the interest, the theory, and the status quo component of constitutional choice). Combining these allows us to examine what actors conceive to be the relevant criteria for their 
choice of rules: does institutional delegation have to be Pareto superior to the current setting, and if so, does institutional change-as Paretian welfare economics suggests - presuppose mere individual Pareto improvements? Do actors also consider criteria of faimess, such as envy-freeness, equitability, or efficiency (Brams and Taylor $1999,13 \mathrm{ff}$.)? If so, is this only typical of constitutional choice situations as opposed to day-to-day decision making? Does institutional delegation fail because of conflicting substantial positions or undesirable effects that the rules are expected to produce? The ISA findings certainly support our view of constitutional choice that takes a look behind the veil of uncertainty.

\section{APPENDIX}

\section{LIKELIHOOD OF COALITION BUILDING}

Given actors' policy positions, the likelihood that actors $\alpha$ and $\beta$ will collaborate in a coalition is related to their salience-weighted spatial proximity. Let $x_{t}^{* i}$ be the ideal point of actor $i$ regarding issue $t$ in the (multidimensional) policy space $\Omega_{t} \subseteq \mathbf{R}^{n}$. Then, the homogeneity of a coalition $S$ can be defined as the mean similarity of all pairs of coalition members:

$$
h_{t}(S)=\frac{2}{s(s-1)} \sum_{\substack{\alpha, \beta \in S \\ \alpha<\beta}} 1-\frac{s_{t}^{\alpha} s_{t}^{\beta}\left|x_{t}^{* \alpha}-x_{t}^{* \beta}\right|}{\operatorname{diam}_{t}(N)},
$$

where $s_{t}^{i}$ is $i$ 's salience regarding issue $t, s$ denotes the number of actors in $S$, and similarity is normalized by the dispersion of all actors' policy preferences:

$$
\operatorname{diam}_{t}(N)=\left\{\begin{array}{lll}
\max _{\mu, v \in N}\left\{s_{t}^{\mu} s_{t}^{v}\left|x_{t}^{*_{\mu}}-x_{t}^{* v}\right|\right\} & \text { if } \max _{\mu, v \in N}\left\{s_{t}^{\mu} s_{t}^{v}\left|x_{t}^{*_{\mu}}-x_{t}^{* v}\right|\right\} \neq 0 \\
1 & \text { if } \max _{\mu, v \in N}\left\{s_{t}^{\mu} s_{t}^{v}\left|x_{t}^{*_{\mu}}-x_{t}^{* v}\right|\right\}=0
\end{array} .\right.
$$

Note, without losing generality, that the dispersion of $N$ is fixed to unity if the ideal points of all actors are identical. Accordingly, we assume that the likelihood $\pi_{t}(S)$ that a coalition $S$ actually will form depends on how homogeneous it is compared to other coalitions:

$$
\pi_{t}(S)=\frac{h_{t}(S)}{\sum_{T^{\prime} \subseteq N} h_{t}(T)} .
$$

\section{MEASUREMENT OF INCLUSIVENESS AND DECISIVENESS}

Constitutional actors must trade off their individual risk of being excluded against their collective capacity to act in the future. This trade-off between individual and collective level defines the core dilemma of group decision making. Preference for a guaranteed inclusion of their future policy positions leads to unanimity rule with high status quo bias, whereas majority rules increase the likelihood of policy change by allowing some actors to be excluded. Formally, an arbitrary voting rule can be depicted as a simple game that is a map $v_{j}$ with $v_{j}(S)=1$, if $S$ is a win- 
ning coalition with respect to the rule, and $v_{j}(S)=0$ if $S$ is losing, where $S$ is a subset of the player set $N$. By definition, $S$ is winning if there is a subset $T$ of $S$ that is winning. For any rule $j$, we denote its corresponding set of winning coalitions by $W_{j}=\left\{S \subseteq N \mid \nu_{j}(S)=1\right\}$.

The collective potential for policy change can thus be calculated as the probability that any of the winning coalitions (able to alter the status quo) will form. At the individual level, we define the inclusiveness $\omega_{j, t}$ of an actor $i$ regarding an issue $t$ as its probability of participating in a winning coalition.

$$
\omega_{j, t}^{j}:=\omega_{i}^{i}\left(v_{j}\right)=\frac{\sum_{S \in W_{j}, i \in S} \pi_{t}(S)}{\sum_{S \in W_{j}} \pi_{t}(S)} .
$$

If all coalitions are equally probable, the potential for policy change is given by the ratio between the number of winning coalitions and all feasible coalitions (Coleman 1971, 278), andinclusiveness of an actor is the number of times he or she participates in winning coalitions in relation to the number of all feasible winning coalitions (König and Bräuninger 1998).

Another property refers to the equity principle in group decision making. Although the international system is generally based on the principle of sovereign states' equity, prerogatives in terms of veto rights, voting weights, and permanent seats are well-known from the United Nations Security Council, the European Union Council of Ministers, and the International Seabed Authority Council. These privileges differentiate actors' decisiveness to influence factual outcomes. Compared to the inclusiveness property of rules, the measurement of decisiveness has already been studied by many relative voting-power analyses (Banzhaf 1965; Shapley and Shubik 1954; Fishburn and Brams 1996). Almost all of these voting power indices calculate an actor's relative ability to be decisive on the transformation of a losing into a winning coalition. The probability of being decisive is thus considered to reflect the actor's chances in realizing his or her own policy position.

However, because an actor's decisive position is only relevant for his or her chances within a winning coalition, we apply a conditional relative voting power index to measure actors' decisiveness. We calculate conditional Shapley-Shubik indices with respect to each (existing) winning coalition because different winning coalitions may have different sets of decisive members with different policy positions. We define conditional Shapley-Shubik indices with respect to an arbitrary winning coalition $S$ by

$$
\phi_{j, S}^{i}:=\phi_{S}^{i}\left(\mathrm{v}_{j}\right)=\sum_{T \subseteq S} \frac{(t-1) !(s-t) !}{s !}\left[\mathrm{v}_{j}(T)-\mathrm{v}_{j}(T /\{i\})\right],
$$

where $s$ and $t$ denote the number of elements of the coalition $S$ and the subcoalitions $T$, respectively. For our purpose, we combine these indices to indicate the probability of an actor being able to realize his or her policy position. This combination enables us to estimate gains and losses actors can expect from decision making under rather specific rules.

\section{EXPECTED OUTCOMES OF COALITIONS}

To assess expected outcomes in a policy area $t$ and actors' expected profits from outcomes, we distinguish between the status quo $\left(s q_{t}\right)$ and the outcomes of all feasible winning coalitions. If the coalition supporting a policy proposal is losing, the status quo remains. In contrast, if the supporting coalition is winning, the policy proposal is the decision-making outcome. Formally, 
we assign every coalition $S$ an expected outcome $x_{j, t}(S)$ in the space of all feasible outcomes $\Omega_{t} \subseteq \mathbf{R}^{n}$ :

$$
x_{j, t}: S \rightarrow x_{j, t}(S) \text {, where } x_{j, t}(S)=s q_{t} \text { if } S \subseteq W_{j}
$$

Given the knowledge of preferences, we assume that decisive actors are able to realize their first preference in the corresponding winning coalition. Then, the expected outcome of a specific winning coalition $S$ is a linear combination of the first preferences of coalition members in which actors' conditional decisiveness indicates how often they are able to realize their own preference within $S$. Let $x_{t}^{* i}$ be the ideal point of actor $i$ regarding issue $t$. Then, actors expect the following policy outcome:

$$
x_{j, t}(S)=\sum_{i \in S} \phi_{j, S}^{i} x_{t}^{* i} \forall S \in W_{j} .
$$

\section{EXPECTED UTILITY OF RULES}

Consider a general utility function $U^{i}=U^{i}(x)$. Then, the expected utility $E U_{j, t}^{i}$ of actor $i$ for rule $j$ regarding issue $t$ is given by

$$
E U_{j, t}^{i}=\sum_{S \subseteq N} \pi_{t}(S) U^{i}\left(x_{j, t}(S)\right)=q_{t} U^{i}\left(s q_{t}\right)+\sum_{S \in W_{j}} \pi_{t}(S) U^{i}\left(\sum_{k \in s} \phi_{j, S}^{k} x_{t}^{* k}\right)
$$

where the status quo probability is $q_{t}=\sum_{S \notin W_{j}} \pi_{t}(S)$, and the actor's probability of being in one out of all winning coalitions is its individual inclusiveness, that is, $\sum_{S \in W_{j}, i \in S} \pi_{t}(S)=\omega_{j, t}$. Note that if all coalitions are equally probable, $(\mathbf{A} 8)$ reduces to

$$
E U_{j, t}^{i}=\left(1-\frac{1}{2^{n}} \sum_{S \in W_{j}} 1\right) U^{i}\left(s q_{t}\right)+\frac{1}{2^{n}} \sum_{S \in W_{j}} U^{i}\left(\sum_{k \in S} \phi_{j, S}^{k} x_{t}^{* k}\right)
$$

as each coalition has a probability of $1 / 2^{n}$.

\section{REFERENCES}

Anderson, D. H. 1995. Resolution and agreement relating to the implementation of Part XI of the UNConvention on the Law of the Sea: A general assessment. Zeitschrift fiur ausländisches öffentliches Recht und Völkerrecht 55:275-89.

Axelrod, R. 1984. The evolution of cooperation. New York: Basic Books.

Banzhaf, J. F. 1965. Weighted voting doesn't work: A mathematical analysis. Rutgers Law Review 19:317-43.

Beyerlin, U. 1996. State community interests and institution-building in international environmental law. Zeitschrift fuir ausländisches öffentliches Recht und Völkerrecht 56:602-27.

Brams, S., and A.D. Taylor. 1999. The win-win solution: Guaranteeing fair shares to everybody. New York: Norton.

Brown, E. D. 1983. Freedom of the high seas versus the common heritage of mankind: Fundamental principles in conflict. San Diego Law Review 20:521-60. -1994. The international law of the sea. Aldershot, UK: Dartmouth.

Buchanan, J. M., and G. Tullock. 1962. The calculus of consent: Logical foundations of constitutional democracy. Ann Arbor: University of Michigan Press. 
Coleman, J. S. 1971. Control of collectivities and the power of a collectivity to act. In Social choice, edited by B. Lieberman, 269-99. New York: Gordon and Breach.

Dupuy, R. -J., and D. Vignes, eds. 1991. A handbook on the new law of the sea. Dordrecht, the Netherlands: Martinus Nijhof.

Edwards, V. M., and N. A. Steins. 1998. Developing an analytical framework for multiple-use commons. Journal of Theoretical Politics 10:347-83.

El-Baghdadi, M. 1990-1991. The binding nature of the disputes settlement procedure in the Third U.N.Convention on the Law of the Sea: The international seabed authority. Joumal of Mineral Law and Policy 6:173-83.

Evans, P. B., H. K. Jacobson, and R. D. Putnam, eds. 1993. Double-edged diplomacy: International bargaining and domestic politics. Berkeley: University of California Press.

Fishburn, P. C., and S. J. Brams. 1996. Minimal winning coalitions in weighted-majority voting games. Social Choice and Welfare 13:397-417.

Foders, F. 1985. Who gains from deep-sea mining? In The economics of deep-sea mining, edited by J. B. Donges, 336-69. Berlin: Springer.

Friedheim, R. L. 1993. Negotiating the new ocean regime. Columbia: University of SouthCarolina Press.

Friedheim, R. L., K. W. Goudreau, W. J. Durch, and J. B. Kadane. 1977. Forecasting outcomes of multilateral negotiations: Methodology. Center for Naval Analyses Research Contributions, Vol. 291. Arlington, VA: Center for Naval Analyses.

Hayashi, M. 1996. The 1994 agreement for the universalization of the law of the sea convention. Ocean Development and International Law 27:31-39.

Hollick, A. L. 1981. U.S. foreign policy and the law of the sea. Princeton, NJ: Princeton UniversityPress.

Ikenberry, G. J., D. A. Lake, and M. Mastanduno. 1988. Introduction: Approaches to explaining American foreign economic policy. International Organization 42:1-14.

Joyner, C. C. 1996. The United States and the new law of the sea. Ocean Development and International Law 27:41-58.

Joyner, C. C., and E. A. Martell. 1996. Looking back to see ahead: UNCLOS III and lessons for global commons law. Ocean Development \& International Law 27:73-95.

Knight, J., and I. Sened, eds. 1995. Explaining social institutions. Ann Arbor: University of Michigan Press.

König, T., and T. Bräuninger. 1998. The inclusiveness of European decision rules. Journal of Theoretical Politics 10:125-41.

Larson, D. L., M. W. Roth, and T. I. Selig. 1995. An analysis of the ratification of the UN Convention on the Law of the Sea. Ocean Development and International Law 26:287-303.

Mero, J. L. 1965. The mineral resources of the sea. New York: Elsevier.

Mueller, D. C. 1996. Constitutional democracy. New York: Oxford University Press.

Nyhart, J.D. 1978. A cost model of deep ocean mining and associated regulatory issues. MITSG 78-4. Cambridge: MIT Press.

Ostrom, E. 1990. Governing the commons: The evolution of institutions for collective action. New York: Cambridge University Press.

Pahre, R., and P. A. Papayoanou, eds. 1997. Newgames: Modeling domestic-international linkages [Special issue]. Journal of Conflict Resolution 41.

Putnam, R. D. 1988. Diplomacy and domestic politics: The logic of two-level games. International Organization 42:427-60.

Schmidt, M. G. 1989. Common heritage or common burden? The United States position on the development of a regime for deep sea-bed mining in the law of the sea convention. Oxford, UK: Clarendon.

Sebenius, J. K. 1984. Negotiating the law of the sea. Cambridge, MA: Harvard University Press.

Shapley, L. S., and M. Shubik. 1954. A method for evaluating the distribution of power in a committee system. American Political Science Review 48:787-92.

Sommer, J. 1996. Environmental law-making by international organisations. Zeitschrift für ausländisches offentliches Recht und Völkerrecht 56:628-67.

Sugden, R. 1981. The political economy of public choice. Oxford, UK: Martin Robertson.

Tsebelis, G. 1990. Nested games. Berkeley: University of California Press.

Vanberg, V., and J. M. Buchanan. 1989. Interests and theories in constitutional choice. Joumal of Theoretical Politics 1:49-62. 
Wijkman, P. M. 1981. Resource regimes proposed by UNCLOS III: A review of ICNT/Rev. I. Stockholm: Institute of International Economic Studies.

Wolfrum, R. 1984. Die Intemationalisierung staatsfreier Räume. Berlin: Springer

1995. The decision-making process according to Sec. 3 of the annex to the implementation agreement: A model to be followed for other international economic organisations? Zeitschrift fiur ausländisches öffentliches Recht und Völkerrecht 55:310-28.

Yost, K. E. 1983. The international sea-bed authority decision-making process: Does it give a proportionate voice to the participant's interests in deep sea mining? San Diego Law Review 20:659-78.

Young, O. R. 1989. Intemational cooperation. Ithaca, NY: Cornell University Press. 